\title{
PENGEMBANGAN PERANGKAT PEMBELAJARAN DENGAN PENDEKATAN CTL MENGGUNAKAN MODEL KOOPERATIF GROUP INVESTIGATION UNTUK MELATIHKAN KETERAMPILAN BERPIKIR KRITIS SISWA SMA PADA MATERI FLUIDA STATIS
}

\author{
Endah Mardewanti \\ Mahasiswa Program Studi Pendidikan Sains, Program Pascasarjana Universitas Negeri Surabaya \\ E-mail: endah.mardewanti@yahoo.com
}

\begin{abstract}
Abstrak: Penelitian ini bertujuan untuk menghasilkan perangkat pembelajaran yang dapat digunakan melatihkan keterampilan berpikir kritis siswa yang dikelola dengan pendekatan CTL menggunakan model Group Investigation. Penelitian ini dilaksanakan dalam dua tahap, yaitu tahap persiapan yang bertujuan mengembangkan perangkat pembelajaran dan tahap kedua tahap uji coba perangkat. Perangkat pembelajaran yang dikembangkan berupa Rencana Pelaksanaan Pembelajaran (RPP), Lembar Kerja Siswa (LKS), Buku Ajar Siswa (BAS), dan tes Keterampilan Berpikir Kritis (KBK). Keterampilan berpikir kritis yang dilatihkan meliputi merumuskan masalah, memberikan argumen, menganalisis, dan menyimpulkan. Perangkat dikembangkan dengan langkah-langkah pengembangan dari Borg and Gall, kemudian dilanjutkan dengan uji coba di SMA Plus Sabilur Rosyad di kelas X-IPA1 dan X-IPA2 dengan menggunakan rancangan pretest-postest design. Data dikumpul berdasarkan penilaian validator, observasi, tes, dan keterbacaan BAS yang dikumpul dengan menggunakan teknik close procedure. Data yang terkumpul kemudian dianalisis menggunakan analisis data secara deskriptif. Hasil analisis data diperoleh sebagai berikut: kualitas perangkat pembelajaran yang dikembangkan dinyatakan valid oleh pakar/validator; tingkat keterbacaan BAS sangat tinggi dan mudah dipahami; RPP mencapai keterlaksanaan yang sangat baik; aktivitas siswa yang menonjol adalah merumuskan masalah; kendala yang terjadi dalam proses pembelajaran adalah siswa belum terbiasa melakukan penyelidikan, sehingga membutuhkan pengarahan terlebih dahulu. Keterampilan berpikir kritis siswa masuk dalam kategori tinggi. Respon siswa terhadap pembelajaran baik, sehingga dari hasil analisis data, dapat disimpulkan bahwa perangkat pembelajaran dengan pendekatan CTL menggunakan model kooperatif Group Investigation pada materi fluida statis dapat digunakan untuk melatihkan keterampilan berpikir kritis siswa.
\end{abstract}

Kata kunci: model Group Investigation, Pendekatan CTL, Keterampilan Berpikir Kritis

Abstract: This study aims to accustome the ability of critical thinking skills of students who managed CTL approach using model Group Investigation. This study was conducted in two phases, the preparation phase which aims to develop learning package and the second phases of the trail of the device. Learning package developed in the form of lesson plan (RPP), Students worksheet (LKS), text books (BAS), and critical thingking skills test (TBK). Critical thinking skills are trained include formulating the problem, provide argument, analize and conclude. The device was developed with the development step of Borg and Gall, then proceed with the trial in the classroom by using pretest-posttest design. Data collected by expert judgement, observation, testing, and legibility BAS were collected using techniques close procedure. The collected data were then analized using descriptive analysis. Results of data analysis obtained as follows the quality of learning package developed by expert declared valid by validator. extremely high level of legibility and easy to understand, RPP achieve excellent, student activity that stand out is formulating a problem; student activity that stands out is formulating a problem; obstades that occur in the learning process is that students are not familiar investigations, thus requiring a briefing before hand. Critical thinking skills of students in the high category. Students' response to the lessons learned, so of data analysis can be concluded that the learning package by using CTL approach GI type cooperative model in the static fluid material can be used to train students' critical thinking skill

Keywords: Group Investigation Model, Managed CTL), Critical Thinking Skill

\section{PENDAHULUAN}

Berpikir kritis merupakan salah satu bagian dari keterampilan atau kemampuan berpikir tingkat tinggi (Alvino, 1990). Berpikir kritis adalah sebuah proses untuk mengungkapkan tujuan yang dilengkapi dengan suatu alasan, tentang apa yang dipercaya dan apa yang dilakukan (Ennis, 1996). Berpikir kritis mengacu pada proses dan metodologi dengan menggunakan rasionalitas, wawasan, kesadaran, imajinasi, dan sensibilitas untuk mngkritik dan mengevaluasi suatu obyek (Mainali, 2011). Berpikir kritis pada dasarnya sangat sederhana yaitu kemampuan untuk menganalisis 
dan mengevaluasi informasi. Pemikir kritis memunculkan pertanyaan penting dan masalah, merumuskan sesuatu dengan jelas, mengumpulkan dan menilai informasi yang relevan, menggunakan ide-ide abstrak, berpikir dengan pikiran terbuka, dan berkomunikasi secara efektif dengan orang lain (Duron dkk, 2006).

Berpikir kritis adalah sebuah keterampilan yang didapatkan melalui proses belajar, seseorang tidak serta merta mampu berpikir kritis karena keterampilan ini bukan merupakan sifat yang dapat diwariskan orang tua kepada anaknya, untuk itu perlu adanya upaya untuk mengajarkan tentang bagaimana berpikir kritis. Menurut Derry \& Murphy (dalam Khaerudin, 2013) bahwa pengajaran keterampilan berpikir kritis dapat digabungkan dengan mata pelajaran tertentu dan pengalaman-pengalaman kelas untuk menciptakan suatu budaya berpikir. Pada kurikulum 2013 keterampilan berpikir kritis telah dimasukkan ke dalam kompetensi dasar mata pelajaran fisika. Pentingnya keterampilan berpikir kritis dilatihkan dan dikembangkan dalam pembelajaran fisika karena menurut survey yang dilakukan oleh Partnership for 21th century skills tahun 2006 (Trilling, 2009) menyatakan bahwa kemampuan yang dibutuhkan oleh setiap orang yang memasuki dunia usaha pada masa akan datang adalah kemampuan berpikir. Kemampuan ini berada pada urutan teratas sebagai kemampuan kompetitif yang dibutuhkan pada abad ini.

Fakta tentang berpikir kritis di Indonesia terlihat dari hasil survei PISA (Programme for International Students Assesment) yang dilakukan pada tahun 2006, terungkap bahwa nilai rerata tes literasi sains anak Indonesia adalah 395 yang menempatkan Indonesia pada peringkat ke 50 dari 65 negara peserta PISA. Hasil literasi sains dari PISA kemudian dianalisis oleh Tim Literasi Sains Puspendik dan diperoleh fakta, diantaranya adalah: (1) komposisi jawaban siswa mengindikasikan lemahnya pemahaman siswa terhadap konsep-konsep dasar sains yang sebenarnya telah diajarkan, sehingga siswa tidak mampu mengaplikasikannya untuk menginterpretasi data, menerangkan hubungan kausal, serta memecahkan masalah sederhana; (2) lemahnya kemampuan siswa dalam membaca dan menafsirkan data dalam bentuk gambar, tabel, diagram, dan bentuk penyajian lainnya; (3) keterbatasan kemampuan siswa mengungkapkan pikiran dalam bentuk tulisan; (4) ketelitian siswa membaca masih rendah, sehingga siswa tidak terbiasa menghubungkan informasi-informasi dalam teks untuk dapat menjawab soal; (5) kemampuan nalar ilmiah masih rendah; (6) lemahnya penguasaan siswa terhadap konsep-konsep dasar sains dan keterkaitannya dengan kehidupan sehari-hari (Mahyuddin, 2007). Fakta lain juga didapatkan dari hasil prapenelitian yang dilakukan oleh penulis pada kelas X-IPA1 SMA Plus Sabilur Rosyad yang berjumlah 32 siswa, dari lima soal keterampilan berpikir kritis siswa yang diberikan hanya $13,3 \%$ siswa yang menjawab benar. Hal ini mengindikasikan bahwa pemahaman siswa dalam menyelesaikan persoalan yang berhubungan dengan keterampilan berpikir tingkat tinggi (berpikir kritis) masih rendah.

Rendahnya berpikir kritis menurut Prasetyowati (2013) dikarenakan pada saat pembelajaran memahami konsep, kemampuan berpikir tingkat tinggi belum diberdayakan, sehingga siswa tidak dapat membangun pengetahuan sendiri. Hardianto (2009) dalam penelitiannya mengungkapkan berpikir kritis yang rendah diakibatkan siswa kurang terlatih untuk mengembangkan daya nalarnya dalam memecahkan permasalahan dan mengaplikasikan konsep-konsep yang telah dipelajari dalam kehidupan nyata. Kedua penyebab ini tentunya perlu dicari pemecahannya mengingat pentingnya keterampilan berpikir kritis ini dalam kehidupan siswa di masa yang akan datang.

Salah satu upaya yang dapat dilakukan untuk memaksimalkan peran aktif siswa dalam membangun pengetahuan dan mengembangkan kemampuan berpikir siswa adalah dengan menggunakan pendekatan atau model pembelajaran yang melibatkan siswa secara langsung dalam pembelajaran (Dahar, 1985). Contextual Teaching and Learning adalah pendekatan pembelajaran yang mengaitkan antara materi yang dipelajari dengan kehidupan nyata siswa sehari-hari, baik dalam lingkungan keluarga, sekolah masyarakat maupun warga negara, dengan tujuan untuk menemukan makna materi tersebut bagi kehidupannya (Komalasari, 2010). Menurut Siroj (2011) ciri-ciri dari suatu pembelajaran konstruktivis adalah (1) tersedianya pengalaman belajar yang mampu mengaitkan pengetahuan yang telah dimiliki siswa; (2) adanya penyelesain masalah dengan berbagai alternatif; (3) dalam proses pembelajaran terjadi interaksi dan kerjasama antara siswa dengan siswa ataupun siswa dengan guru; dan (4) terdapat media sebagai alat agar pembelajaran menjadi lebih efektif. Menurut Dikdasmen (2003) CTL terdapat tujuh pilar, adapun pilar-pilar yang dapat mendukung suatu pembelajaran membangun pengetahuan adalah pilar konstruktivisme, inkuiri, masyarakat belajar.

Menurut Khaerrudin (2013) dalam proses menumbuhkan keterampilan berpikir kritis guru memberikan kesempatan kepada siswa untuk mengambil peran dalam kerjasama dalam memecahkan masalah. Ini berarti dalam proses pembelajaran dibutuhkan suatu model pembelajaran kooperatif yang dapat mengaktifkan siswa dalam memecahkan masalah. Model pembelajaran kooperatif yang bermuara pada penyelesaian masalah adalah Group Investigation. 
Model pembelajaran Group investigation adalah model pembelajaran yang sesuai untuk studi proyek yang terintegrasi dan berhubungan dengan hal-hal semacam penguasaan, analisis, dan mensintesiskan informasi sehubungan dengan upaya menyelesaikan masalah yang bersifat multi aspek (Slavin, 2006). Penyelidikan adalah salah satu fase dari Group investigation dalam fase ini siswa dituntut untuk melakukan penyelidikan dan memecahkan permasalahan yang sedang dihadapinya.

Perangkat pembelajaran adalah suatu media atau sarana yang digunakan sebagai petunjuk dan pedoman yang digunakan seorang guru untuk mencapai suatu keberhasilan dalam pembelajaran. Perangkat permbelajaran memuat silabus, RPP, materi ajar, LKS dan tes hasil belajar. Menurut Mulyasa (2006) perangkat pembelajaran memiliki dua fungsi yaitu fungsi perencanaan dan fungsi pelaksanaan dalam fungsi perencanaan perangkat pembelajaran adalah sarana untuk mempersiapkan sebuah pembelajaran, dan dalam fungsi pelaksanaan, perangkat pembelajaran adalah sarana untuk mengefektifkan proses pembelajaran sesuai dengan apa yang telah direncanakan. Menilik pentingnya keterampilan berpikir kritis dalam kehidupan, maka penulis menggunakan pendekatan CTL dan kooperatif tipe Group Investigation yang diejawantahkan dalam suatu perangkat pembelajaran yang diharapkan mampu membangun pengetahuan dan mengembangkan daya nalar siswa, sehingga siswa dapat menjadi seorang pemikir kritis.

Dari uraian di atas rumusan masalah dalam penelitian ini adalah bagaimana validitas teoritis, kepraktisan, dan efektivitas perangkat pembelajaran materi fluida statis yang dikembangkan mengacu kepada pendekatan CTL dan model kooperatif Group Investigation dalam melatihkan keterampilan berpikir kritis siswa?

Penelitian ini bertujuan untuk menghasilkan perangkat pembelajaran dengan pendekatan CTL menggunakan model koopratif Group Investigation yang tervalidasi secara teoritis, praktis, dan efektif.

\section{METODE PENELITIAN}

Penelitian ini termasuk penelitian pengembangan atau Research and Development $(R \& D)$. Produk yang dikembangkan dalam penelitian ini adalah perangkat pembelajaran untuk melatihkan keterampilan berpikir siswa yang meliputi: (1) RPP, (2) LKS, (3) Buku siswa, (4) Soal tes berpikir kritis. Langkah-langkah pengembangan produk diadaptasi dari Borg and Gall (dalam Fauziyah, 2013) yang memuat tahapan: (1) pengembangan produk awal, (2) Validasi ahli, (3) revisi, (4) uji coba I, (5) revisi, dan (6) uji coba. Uji coba mengikuti rancangan penelitian One Group Pretest-Postest Design. Subyek pada penelitian ini adalah perangkat pembelajaran. Validitas perangkat pembelajaran diperoleh dari penilain expert judgement yaitu tiga orang ahli dalam bidang pendidikan, kepraktisan perangkat pembelajaran diperoleh dari penilaian pengamat saat uji coba, dan untuk mengetahui keefektifan perangkat pembelajaran diperlukan uji coba kepada siswa.

Data dikumpul berdasarkan penilaian validator, observasi, tes, dan keterbacaan BAS yang dikumpul dengan menggunakan teknik close procedure. Data yang terkumpul kemudian dianalisis menggunakan analisis secara deskriptif

\section{HASIL PENELITIAN DAN DISKUSI}

Perangkat yang telah dikembangkan oleh peneliti, kemudian divalidasi olh para pakar dan slanjutnya dilakukan uji coba kepada siswa SMA Plus Sabilur Rosyad. Uji coba ini bertujuan untuk mengetahui bagaimana kepraktisan dan keefektifan dari perangkat pembelajaran yang dikembangkan, karena menurut Nievieen (1999) suatu produk pengembangan dikatakan layak apabila produk tersebut valid, praktis, dan efektif. Berikut ini hasil pengembangan perangkat yang telah diujicobakan kepada siswa.

\section{A. Kualitas Hasil Pengembangan Perangkat Pembelajaran}

1. Hasil Validasi RPP

Aspek yang divalidasi dari RPP yang dikembangkan meliputi konstruk, isi, dan bahasa. Hasil validasi RPP disajikan dalam Tabel 1.

Tabel 1. Hasil Validasi RPP

\begin{tabular}{|c|c|c|c|}
\hline $\begin{array}{c}\text { Aspek yang } \\
\text { diamati }\end{array}$ & $\begin{array}{c}\text { Rerata Penilaian } \\
\text { Validator }\end{array}$ & Ket & $\begin{array}{c}\text { Percentage } \\
\text { Agreement }\end{array}$ \\
\hline Konstruk & 3,1 & Valid & $95 \%$ \\
\hline Isi & 3,3 & Valid & $92 \%$ \\
\hline $\begin{array}{c}\text { Kelugasan } \\
\text { Bahasa }\end{array}$ & 3 & Valid & $100 \%$ \\
\hline
\end{tabular}

Berdasarkan Tabel 1 dapat diketahui bahwa hasil tersebut menyatakan RPP yang dikembangkan masuk dalam kategori valid dan dapat digunakan dengan sedikit revisi (Ratumanan dan Laurent, 2008), kesepahaman para ahli tentang RPP masuk dalam kategori baik (Borich, 1994).

2. Hasil Validasi Buku Ajar Siswa (BAS)

Tabel 2. Hasil Validasi BAS

\begin{tabular}{|c|c|c|c|}
\hline $\begin{array}{c}\text { Aspek yang } \\
\text { diamati }\end{array}$ & $\begin{array}{c}\text { Rerata Penilaian } \\
\text { Validator }\end{array}$ & Ket & $\begin{array}{c}\text { Percentage } \\
\text { Agreement }\end{array}$ \\
\hline Konstruk & 3,6 & Valid & $94 \%$ \\
\hline Isi & 3,2 & Valid & $95 \%$ \\
\hline $\begin{array}{c}\text { Kelugasan } \\
\text { Bahasa }\end{array}$ & 3 & Valid & $100 \%$ \\
\hline
\end{tabular}

Hasil validasi BAS berdasarkan Tabel 2 dinyatakan sangat valid (Ratumanan dan Laurent, 2011) dan kesepahaman para ahli tentang BAS pada kategori baik (Borich, 1994). 


\section{Hasil Validasi LKS}

Tabel 3. Hasil Validasi LKS

\begin{tabular}{|l|l|l|l|}
\hline Aspek yang diamati & LKS I & LKS II & LKS III \\
\hline Konstruk & 3,2 & 3 & 3,5 \\
\hline Isi & 3,3 & 3,3 & 3,4 \\
\hline Kelugasan Bahasa & 3,5 & 3,5 & 3 \\
\hline
\end{tabular}

Berdasarkan Tabel 3 skor untuk aspek konstruk ketiga LKS berada diantara 3 sampai dengan 3,5, sedangkan dari aspek isi ketiga LKS memperoleh skor antara 3,3 sampai dengan 3,4, dan aspek bahasa ketiga LKS memperoleh skor antara 3 sampai dengan 3,5. Sehingga LKS dari aspek konstruk dinyatakan valid (Ratumanan dan Laurent, 2011) dan dapat digunakan dengan sedikit revisi.

\section{Hasil Validasi Tes KBK}

Soal tes Keterampilan Berpikir Kritis (KBK) terdiri dari 8 soal bentuk uraian yang meliputi empat indikator berpikir kritis yang dilatihkan yaitu merumuskan masalah, memberikan argumen, menganalisis data, dan menyimpulkan. Soal tes KBK yang dikembangkan oleh peneliti divalidasi oleh validator dari aspek isi dan kelugasan kalimat. Hasil validasi oleh para validator dapat dilihat pada Tabel 4.

Tabel 4. Hasil Validasi KBK

\begin{tabular}{|l|c|c|}
\hline \multirow{2}{*}{ Indikator } & Isi & Kelugasan Bahasa \\
\cline { 2 - 3 } & Rerata 3 Validator & Rerata 3 Validator \\
\hline 1 & 3,3 & 3 \\
\hline 2 & 3 & 3 \\
\hline 3 & 3,3 & 3,7 \\
\hline 4 & 3,3 & 3 \\
\hline 5 & 3 & 3 \\
\hline 6 & 3,3 & 3,3 \\
\hline 7 & 3,3 & 3,3 \\
\hline 8 & 3,3 & 3 \\
\hline Rerata & 3,3 & 3,2 \\
\hline
\end{tabular}

\section{Keterbacaan BAS}

Penilaian keterbacaan BAS dilakukan oleh siswa. Hasil keterbacaan BAS yang diproleh dengan teknik close procdure, memberikan hasil bahwa BAS yang dikembangkan oleh peneliti masuk dalam kategori tinggi dan dapat digunakan dalam pembelajaran (Suryadi, 2007).

\section{B. Hasil Uji Coba Perangkat Pembelajaran}

Perangkat pembelajaran yang dikembangkan kemudian diujicobakan di SMA Plus Sabilur Rosyad dengan subyek penelitian siswa kelas X IPA-1 dan X IPA 2 yang masing-masing kelas berjumlah 32 siswa. Data hasil penelitian dianalisis menggunakan statistic deskriptif dalam bentuk rata-rata nilai dan persentase. Hasil uji coba ini untuk mengtahui kepraktisan dan keefektifan dari perangkat pembelajaran yang telah dikembangkan oleh peneliti.
1. Kepraktisan Perangkat Pembelajaran

a) Keterlaksanaan RPP

Hasil keterlaksanaan RPP yang dilakukan oleh guru dalam kegiatan pembelajaran yang diamati dan dicatat oleh pengamat dengan menggunakan lembar pengamatan keterlaksanaan RPP, diperoleh dari menghitung rata-rata nilai yang diberikan oleh kedua pengamat, dapat dilihat pada Tabel 5 sebagai berikut:.

Tabel 5. Penilaian Keterlaksanaan RPP

\begin{tabular}{|l|l|l|l|l|l|l|}
\hline \multirow{2}{*}{ Fase } & \multicolumn{3}{|l|}{ Kelas A (pert ke-) } & \multicolumn{3}{l|}{ Kelas B (pert ke-) } \\
\cline { 2 - 7 } & I & II & III & I & II & III \\
\hline Fase I & 3,6 & 3,7 & 3,7 & 3,3 & 3,6 & 3,7 \\
\hline Fase II & 3,5 & 3,5 & 3,5 & 3,5 & 3 & 4 \\
\hline Fase III & 3,5 & 3,5 & 3,5 & 3,4 & 3,1 & 3,5 \\
\hline Fase IV & 3,5 & 3,5 & 3,5 & 3,3 & 3,3 & 3,5 \\
\hline Fase V & 3,3 & 3,5 & 3,5 & 3 & 3,5 & 3,8 \\
\hline Fase VI & 3,5 & 3,5 & 4 & 3,5 & 3,5 & 4 \\
\hline Rata-rata & 3,5 & 3,5 & 3,6 & 3,3 & 3,3 & 3,8 \\
\hline
\end{tabular}

Keterlaksanaan RPP secara umum dianalisis untuk tiap pertemuan. Pertemuan I dan II untuk kelas A maupun B skor yang diperoleh diantara 3,3 sampai dengan 3,5. Pertemuan III baik kelas A maupun kelas B fase-fase pembelajaran kooperatif tipe GI telah dapat dilaksanakan dan mendapat penilaian 3,6 sampai dengan 3,8, sehingga pada pertemuan ketiga keterlaksanaan RPP di kelas A maupun B masuk dalam kategori terlaksana dengan sangat baik.

b) Kendala-kendala Selama Proses Pembelajaran

Pelaksanaan pembelajaran dengan pendekatan $C T L$ dengan menggunakan model kooperratif tipe $G I$ ditemukan beberapa hambatan. Kendala-kendala yang terjadi pada saat pembelajaran dapat diatasi oleh peneliti dengan mengkondisikan siswa, memberikan pengarahan, dan menuntun siswa untuk melatihkan keterampilan berpikir kritis baik sebelum pembelajaran atau pada saat proses pembelajaran berlangsung.

\section{Keefektifan Perangkat Pembelajaran}

Peningkatan keterampilan berpikir kritis siswa diproleh dari hasil nilai pretest dan posttest, yang kemudian dianalisis menggunakan analisis peningkatan $N$-Gain dan diinterpretasikan sesuai dengan kategori. Peningkatan $N$-Gain siswa untuk kelas A dan B disajikan dalam bentuk grafik.

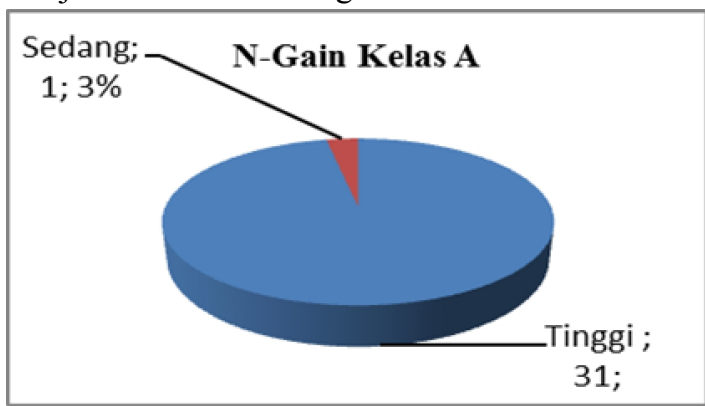

Gambar 1. $N$-Gain Kelas A 


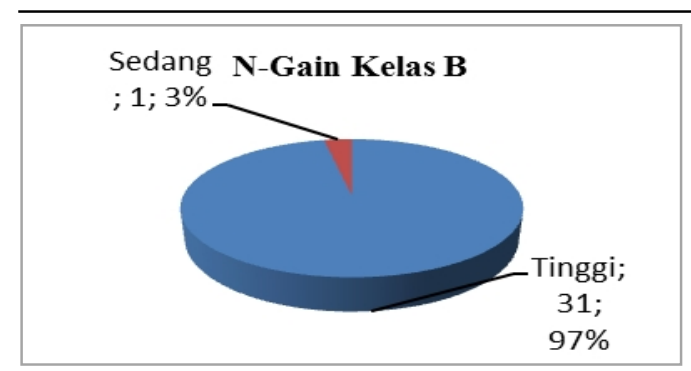

Gambar 2. $N$-Gain Kelas B

Hasil peningkatan keterampilan berpikir kritis siswa yang dilihat dari nilai pretest dan nilai posttest diperoleh nilai rata-rata siswa 0,92 untuk kelas A dan 0,89 untuk kelas B. Dengan hasil tersebut maka peningkatan keterampilan berpikir kritis siswa setelah dilakukan pembelajaran masuk dalam kategori tinggi (Ratumanan dan Lauren, 2008).

1. Ketuntasan Individu

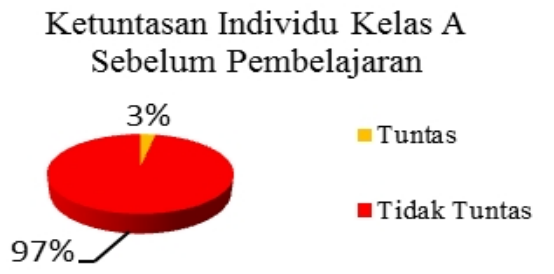

Gambar 3 Ketuntasan Individu Kelas A Sebelum Pembelajaran

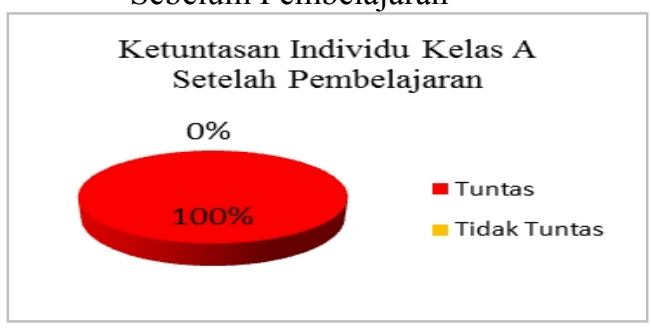

Gambar 4 Ketuntasan Individu Kelas A Setelah Pembelajaran

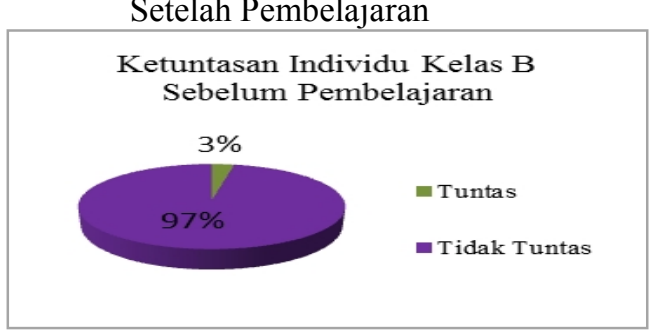

Gambar 5 Ketuntasan Individu Kelas A Sebelum Pembelajaran

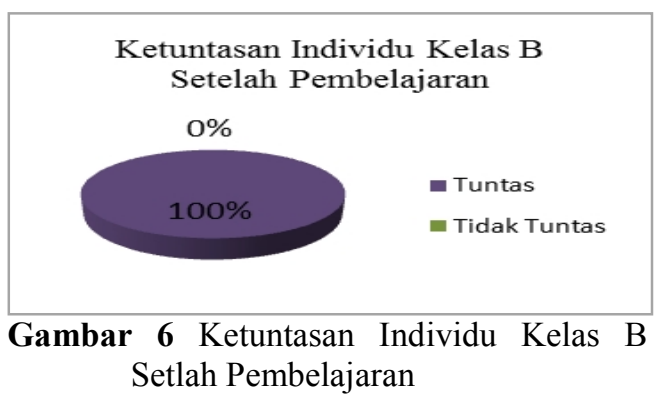

Gambar 3 sampai dengan 6 tentang ketuntasan individu menunjukkan bahwa sebelum dilakukan pembelajaran di kelas A dan kelas B terdapat satu siswa yang dinyatakan tuntas. Setelah dilakukan pembelajaran seluruh siswa baik di kelas A dan B seluruh siswa dinyatakan tuntas.

2. Ketuntasan Indikator

Ketuntasan Indikator Kelas A dan B disajikan pada Tabel 6 dan Tabel 7

Tabel 6. Ketuntasan Indikator Kelas A

\begin{tabular}{|l|l|l|l|l|}
\hline \multirow{2}{*}{\multicolumn{1}{|c|}{ Indikator }} & \multicolumn{4}{|l|}{ Kelas A } \\
\cline { 2 - 6 } & $\mathrm{O}_{1}$ & Ket & $\mathrm{O}_{2}$ & Ket \\
\hline Merumuskan Masalah & 7 & $\mathrm{TT}$ & 29 & $\mathrm{~T}$ \\
\hline Memberikan argumetasi & 4 & $\mathrm{TT}$ & 27 & $\mathrm{~T}$ \\
\hline Menganalisis & 3 & $\mathrm{TT}$ & 26 & $\mathrm{~T}$ \\
\hline Menyimpulkan & 1 & $\mathrm{TT}$ & 25 & $\mathrm{~T}$ \\
\hline
\end{tabular}

Tabel 7. Ketuntasan Indikator Kelas B

\begin{tabular}{|l|l|l|l|l|}
\hline \multirow{2}{*}{\multicolumn{1}{c|}{ Indikator }} & \multicolumn{3}{l}{ Kelas B } \\
\cline { 2 - 6 } & $\mathrm{O}_{1}$ & Ket & $\mathrm{O}_{2}$ & Ket \\
\hline Merumuskan Masalah & 4 & $\mathrm{TT}$ & 26 & $\mathrm{~T}$ \\
\hline Memberikan argumetasi & 4 & $\mathrm{TT}$ & 25 & $\mathrm{~T}$ \\
\hline Menganalisis & 1 & $\mathrm{TT}$ & 24 & $\mathrm{~T}$ \\
\hline Menyimpulkan & 1 & $\mathrm{TT}$ & 24 & $\mathrm{TT}$ \\
\hline
\end{tabular}

\section{Profil KBK Siswa}

Profil Keterampilan Berpikir Kritis Siswa setelah dianalisis dan diinterpretasikan sesuai dengan kriteria disajikan dalam bntuk grafik pada Gambar 7.

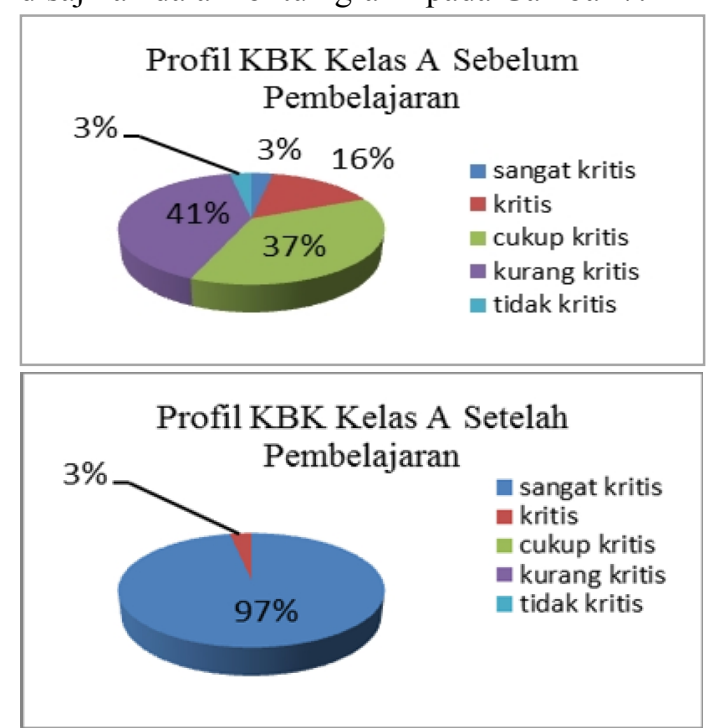

Gambar 7 Grafik Profil KBK Kelas A Sebelum dan Sesudah Pembelajaran

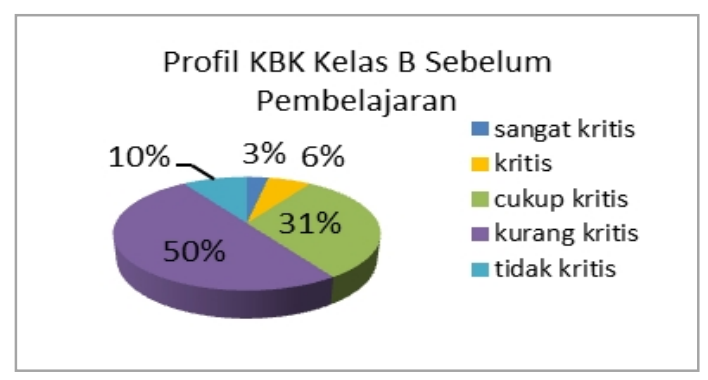

Menggunakan Model Kooperatif Group Investigation untuk ... 


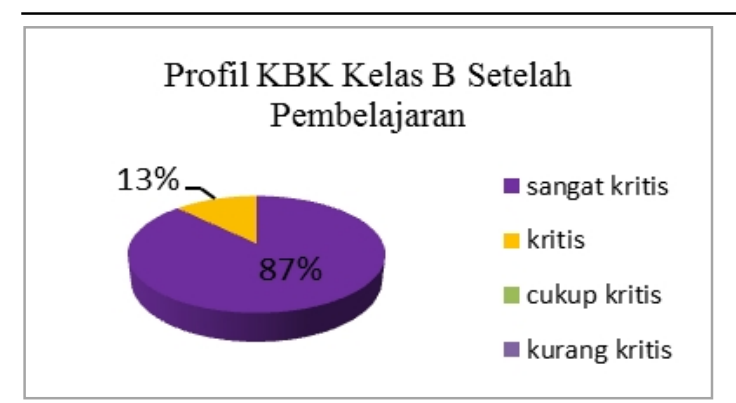

Gambar 8 Profil KBK Kelas B Sebelum dan Sesudah Pembelajaran

Profil berpikir kritis siswa kelas X SMK Plus Sabilur Rosyad sebelum pembelajaran untuk kelas A terdapat $3,1 \%$ siswa yang berkategori sangat kritis, 40,6\% siswa berkategori kurang kritis dan cukup kritis, dan $15,6 \%$ berkategori kritis. Untuk kelas B sebelum pembelajaran 3,1\% siswa berkategori sangat kritis, 6,3\% siswa berkategori kritis, 9,4\% siswa berkategori tidak kritis, 31,3\% siswa berkategori cukup kritis, dan $50 \%$ siswa berkategori kurang kritis. Setelah pembelajaran siswa yang berkategori kritis baik di kelas A dan B berada diantara 3,1\% sampai dengan $12,5 \%$ dan $87,5 \%$ sampai dengan $96,9 \%$ siswa berkategori sangat kritis

\section{Profil KBK Tiap Indikator}

Profil KBK tiap indikator disajikan pada Gambar 9 berikut:

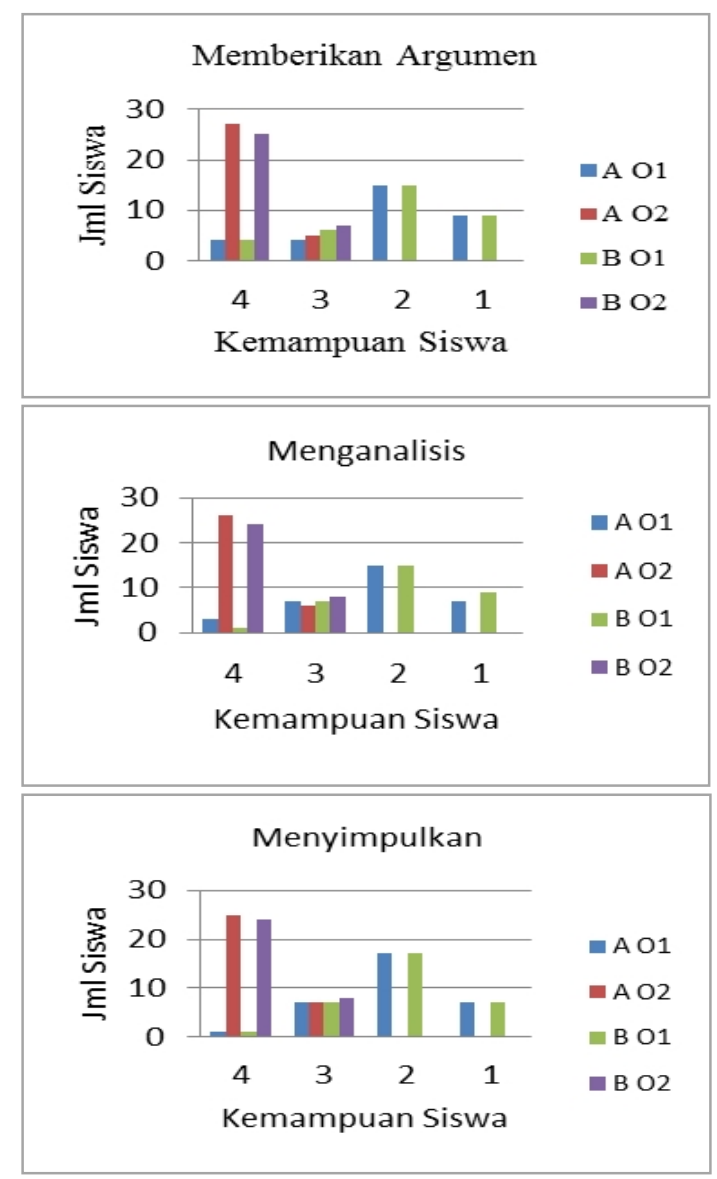

Ket: O1: Pretest

O2: Posttest

Gambar 9 Profil KBK Tiap Indikator
1. Pada indikator merumuskan masalah baik di kelas $\mathrm{A}$ maupun kelas B, sebelum pembelajaran siswa belum tepat dalam mengidentifikasi variabel manipulasi dan variabel respon. Setelah pembelajaran siswa sudah mampu dalam mengidentifikasi variabel respon dan variabel manipulasi.

2. Pada indikator kedua sebelum pembelajaran argumentasi sebagian siswa dibangun tanpa alasan yang tepat, hal ini terjadi baik di kelas A maupun kelas B. Setelah pembelajaran baik siswa kelas A maupun kelas B sudah mampu memberikan argumentasi dan alasan yang tepat.

3. Pada Indikator menganalisis sebelum pembelajaran sebagian siswa di kelas A maupun B tidak tepat dalam menunjukkan hubungan antara variabel manipulasi dan respon. Setelah pembelajaran hampir keseluruhan siswa di kelas A dan B dalam menganalisis sudah tepat dan dapat menunjukkan hubungan antara variabel manipulasi dan variabel respon.

4. Pada Indikator menyimpulkan di kelas A maupun kelas B sebelum pembelajaran, lebih dari separuh siswa tidak tepat dalam menuliskan hubungan antara variabel manipulasi dan respon. Setelah pembelajaran baik di kelas A maupun kelas B hampir seluruh siswa tepat dalam menuliskan hubungan antara variabel manipulasi dengan respon.

Persentase berpikir kritis siswa di kelas A dan B untuk indikator merumuskan masalah (MM) sebelum pembelajaran adalah sebesar $66,41 \%$ dan $59,38 \%$, setelah pembelajaran persentase indikator berpikir kritis siswa mengalami peningkatan hingga mencapai $97,66 \%$ dan $95,31 \%$. Persentase indikator memberikan argumen (MA) sebelum pembelajaran di kelas A dan B adalah sebesar $52,34 \%$ dan $57,03 \%$, setelah pembelajaran indikator ini mengalami peningkatan sehingga persentasenya menjadi $96,09 \%$ dan $94,53 \%$. Untuk indikator ketiga yaitu menganalisis di kelas A dan kelas $\mathrm{B}$ sebelum pembelajaran persentase indikator ini sebesar $49,26 \%$ dan $50,00 \%$ dan mengalami peningkatan setelah pembelajaran hingga persentasenya menjadi $95,31 \%$ dan $93,75 \%$. Persentase indikator menyimpulkan sebelum pembelajaran di kelas A dna B adalah sebesar $46,15 \%$ dan $51,56 \%$, indikator ini juga mengalami peningkatan setelah pembelajaran dengan persentase sebesar $94,53 \%$ dan $93,75 \%$ untuk masingmasing kelas.

\section{Aktivitas Siswa}

Aktivitas siswa yang diperhatikan adalah aktivitas yang dilakukan selama proses pembelajaran menggunakan pendekatan CTL dengan kooperatif tipe GI untuk melatihkan keterampilan berpikir kritis siswa. 
Aktivitas yang tampak mencakup: (1) mendengarkan penjelasan guru; (2) membaca buku siswa (3) merencanakan percobaan; (4) merumuskan masalah; (5) memberikan argumen; (6) merangkai sesuai prosedur; (7) melakukan percobaan; (8) menganalisis; membuat kesimpulan; (10) aktivitas tidak relevan.

Aktivitas siswa mendengarkan penjelsan guru mengalami penurunan dari pertemuan I sampai dengan pertemuan III. Aktivitas kedua membaca buku siswa untuk pertemuan I sampai dengan pertemuan III mengalami penurunan. Peningkatan aktivitas terjadi pada aktivitas ketiga (merencanakan percobaan), empat, dan lima yaitu aktivitas merencanakan percobaan, merumuskan masalah, dan memberikan argumen. Aktivitas keenam dan ketujuh baik kelas A maupun B untuk pertemuan I sampai dengan III mengalami peningkatan. Aktivitas menganalisis dan menyimpulkan dari pertemuan I sampai dengan III mengalami peningkatan, peningkatan tajam pada kedua aktivitas ini terjadi pada pertemuan I ke II. Sedangkan aktivitas yang tidak relevan seperti bercanda dan berbicara dengan teman pada saat pembelajaran berlangsung terjadi penurunan untuk tiap pertemuaannya.

\section{Respon Siswa}

Respon siswa adalah pendapat siswa mengenai pembelajaran dengan pendekatan CTL menggunakan model kooperatif tipe GI. Untuk mengetahui respon siswa berkaitan dengan pembelajaran, siswa diharuskan untuk mengisi angket yang dilakukan setelah KBM. Respon siswa meliputi: (1) ketertarikan siswa terhadap materi, LKS, suasana belajar, dan cara mengajar guru; (2) keterbaharuan BAS; (3) tingkat kesulitan dalam memahami BAS, LKS, dan cara mengajar guru; (4) komponen keterampilan berpikir kritis yang dilatihkan; (5) minat untuk mengikuti pembelajaran pada kompetensi yang lain; (6) tanggapan siswa terhadap penjelasan dan bimbingan guru.

Aspek ketertarikan siswa terhadap materi, LKS, suasana belajar, dan cara mengajar guru diperoleh ratarata untuk dua kelas uji coba adalah sebesar 93\% sampai dengan $96 \%$ hal ini mengindikasikan bahwa respon siswa terhadap aspek tersebut sangat positif. Pada aspek kedua tentang keterbaruan LKS dan keterampilan berpikir kritis, siswa merespon sangat positif, hal ini terlihat dari hasil rata-rata respon siswa yang sebesar $94 \%$ dan $93 \%$. Pada aspek ketiga tentang kemudahan dalam memahami materi, LKS, dan cara mengajar guru diperoleh nilai rata-rata $92 \%$ sampai dengan 94\%, yang mengindikasikan bahwa respon siswa sangat positif. Pada aspek keempat yaitu tentang kemudahan siswa dalam mempelajari komponen keterampilan berpikir kritis pada indikator merumuskan masalah, memberikan argumen, menganalisis data, dan menyimpulkan, siswa memberikan respon sangat positif yang dibuktikan dengan hasil perhitungan respon siswa terhadap aspek tersebut yang masingmasing memperoleh persentase nilai antara $92 \%$ sampai dengan $99 \%$ Pada aspek kelima tentang minat siswa dalam mengikuti pembelajaran siswa memberikan respon sangat positif dengan rata-rata nilai sebesar 94\%. Siswa memberikan respon sangat positif pada aspek keenam yaitu tentang penjelasan guru saat mengajar dan memberikan bimbingan, hal ini diperkuat dengan hasil perhitungan respon siswa sebesar 93\% sampai dengan $94 \%$.

\section{Konsepsi Hasil Penelitian}

Pembelajaran menggunakan model kooperatif tipe GI dengan pendekatan CTL yang dilakukan dalam rangka melatihkan keterampilan berpikir kritis pada penelitian ini dapat terlaksana dengan baik pada tiap pertemuan. Tahapan dalam model pembelajaran Group Investigation mempengaruhi kemampuan berpikir kritis siswa. Pada tahap pengelompokkan dan pemilihan topik mengarahkan siswa untuk dapat mengidentifikasi masalah yang ada dalam kehidupan sehari-hari. Siswa berdiskusi dengan kelompoknya untuk menentukan topik dari permasalahan yang sedang terjadi di sekitar kehidupan mereka. Pada tahap perencanaan dapat mendorong siswa untuk lebih bertoleransi dan berkerjasama antar anggota kelompok karena siswa membagi tugas kelompok masing-masing kepada tiap anggota kelompok, pada tahap ini juga termasuk dalam komponen CTL yang ada dalam penelitian yaitu masyarakat belajar. Tahap investigasi merupakan inti dari model pembelajaran Group Investigation karena siswa mengumpulkan fakta-fakta dari percobaan untuk merumuskan masalah, merumuskan hipotesis, mengidentifikasi variabel, melakukan percobaan, mengumpulkan data hasil percobaan, menganalisis data hasil percobaan, dan menyimpulkan. Pada tahap ini siswa dalam kelompok saling berdiskusi dan memecahkan masalah tentang topik yang dibahas dengan langkah-langkah inkuiri. Selain untuk memecahkan masalah, pada tahap investigasi siswa dapat membangun pengetahuan mereka sendiri melalui proses penyelidikan dengan langkah-langkah inkuiri. Pada tahap ini keterampilan berpikir kritis siswa dapat terbentuk. Keterampilan berpikir kritis merumuskan masalah, menganalisis data, dan menyimpulkan dapat dilatihkan melalui tahap ini.

Pada tahap memyiapkan laporan akhir, anggota kelompok saling berkumpul untuk menyelesaikan laporan. Tiap anggota menentukan pesan penting dari topik yang diteliti. Pada tahap ini aspek keterampilan berpikir yang terbentuk adalah menentukan hasil percobaan dan membuat keputusan. Tujuan dari diskusi adalah untuk mengambil keputusan yang digunakan untuk penyusunan laporan dan presentasi. Penyusunan 
laporan hasil investigasi dikaji dengan konsep materi yang sebenarnya, sehingga dapat diterima secara ilmiah dan hasil analisis investigasi memiliki dasar yang kuat.

Tahap presentasi dilakukan setelah kelompok melakukan kegiatan penyelidikan dan menarik kesimpulan, dilanjutkan dengan presentasi atau menyampaikan jawaban pada semua anggota kelas. Dalam tahap ini aspek keterampilan berpikir kritis yang terbentuk adalah memberikan argumen. Pada tahap ini dapat terbentuk aspek-aspek keterampilan berpikir kritis, karena dalam kegiatan yang dilakukan sangat kompleks, dimana siswa saling bertukar pengetahuan yang ditandai dengan adanya tanya jawab, pemberian pendapat, dan sanggahan.

Tahap evaluasi, pada tahap ini guru memberikan ulasan dan penjelasan secukupnya sebagai klarifikasi dari jawaban siswa. Tahap ini merupakan akhir dari pembentukan pemikiran kritis siswa karena pemikiran kritis siswa sudah terbentuk di sini. Guru memberikan penguatan dari hasil presentasi sehingga kemampuan berpikir kritis siswa lebih tajam.

Pengejawantahan komponen CTL (Konstruktivisme, masyarakat belajar, dan inkuiri) dan model pembelajaran kooperatif Group Investigation dalam perangkat pembelajaran terbukti mampu meningkatkan keterampilan berpikir kritis siswa dengan kategori tinggi. Hasil penelitian menunjukkan bahwa melalui pembelajaran dengan menggunakan model $G I$ dengan pendekatan CTL peningkatan keterampilan berpikir kritis siswa diiringi dengan peningkatan hasil belajar siswa pada ranah pengetahuan. Peningkatan hasil keterampilan berpikir kritis dan hasil belajar tersebut juga diiringi dengan aktivitas belajar siswa yang baik dalam pembelajaran. Respon positif siswa terhadap pembelajaran yang tinggi mendorong siswa untuk aktif dan berkolaborasi sehinggga minat siswa terhadap pembelajaran meningkat, dan pada akhirnya akan menentukan keberhasilan belajar siswa.

Menurut Nievieen dalam Rochmad (2012) kualitas hasil pengembangan harus memenuhi tiga kriteria yaitu: kevalidan, kepraktisan, dan keefektifan. Kevalidan dalam penelitian ini adalah penilaian para pakar terhadap perangkat pembelajaran yang dikembangkan. Hasil penelitian menyatakan bahwa penilaian yang diberikan oleh pakar berkriteria valid. Dari segi kepraktisan Nieveen (1999) menyatakan bahwa tingkat kepraktisan suatu perangkat dapat ditinjau dari bagaimana tingkat keterlaksanaan model perangkat tersebut pada saat dilakukan uji coba. Dalam penelitian ini keterlaksanaan perangkat pembelajaran berkriteria baik, sehingga perangkat pembelajaran yang dikembangkan dapat dikatakan sudah memenuhi syarat dari segi kepraktisan dan dapat digunakan untuk melatihkan keterampilan berpikir kritis. Selain dari hasil pengamatan keterlaksanaan tingkat kepraktisan juga dinilai keterbacaan Buku Ajar Siswa (BAS) dan kendala-kendala yang dapat mempengaruhi keterlaksanaan pembelajaran. Dari hasil keterbacaan dengan kriteria tinggi, sehingga Buku Ajar Siswa dapat digunakan dalam pembelajaran untuk melatihkan keterampilan berpikir kritis. Kendala-kendala yang dihadapi oleh peneliti pada saat proses belajar mengajar harus dapat ditemukan solusinya, agar kendala tersebut tidak muncul lagi pada pertemuan berikutnya sehingga pembelajaran dapat terlaksana dengan baik. Dari segi kepraktisan yang dapat ditinjau dari keterlaksanaan Rencana Pelaksanaan Pembelajaran (RPP), keterbacaan Buku Ajar Siswa (BAS), dan kendala-kendala yang dihadapi selama pembelajaran maka perangkat pembelajaran yang dikembangkan dengan model Group Investigation dengan pendekatan CTL sudah memenuhi syarat dari segi kepraktisan dan dapat digunakan untuk melatihkan keterampilan berpikir kritis.

Keefektifan pembelajaran dapat ditinjau dari respon siswa terhadap pembelajaran, hasil belajar, dan aktivitas siswa. Respon siswa adalah tingkat penghargaan siswa dalam mengikuti pembelajaran, kejelasan guru dalam memberikan informasi, keterbaruan komponen pembelajaran, dan minat siswa untuk mengulang lagi pembelajaran dengan model yang sama pada materi yang lain. Selain itu tingkat keefektifan juga diukur dari hasil belajar yang dalam hal ini adalah hasil tes keterampilan berpikir kritis dan aktivitas siswa. Hasil penelitian yang dilakukan menunjukkan bahwa keterampilan berpikir kritis siswa mengalami peningkatan setelah diterapkan pembelajaran dengan menggunakan model Group Investigation dengan pendekatan Contextual (CTL) dengan kategori tinggi. Keterampilan berpikir kritis siswa dapat dilihat dari perbedaan profil berpikir kritis sebelum dan sesudah pembelajaran. Profil berpikir kritis siswa mengalami peningkatan dari tidak kritis menjadi kritis setelah dilakukan pembelajaran. Presentase aktivitas siswa dalam pembelajaran menunjukkan peningkatan pada aktivitas yang relevan dan mendukung pembelajaran. Hal ini menunjukkan bahwa perangkat pembelajaran yang dikembangkan oleh peneliti sudah memenuhi syarat dari segi kevalidan, kepraktisan, dan keefektifan sehingga pengembangan perangkat pembelajaran yang dilakukan oleh peneliti dapat digunakan dan dikatakan berkualitas. Selain itu perangkat pembelajaran dengan model GI dengan pendekatan CTL ini juga dapat digunakan untuk melatihkan keterampilan berpikir kritis siswa khususnya pada materi fluida statis.

Hambatan yang sering ditemukan pada pembelajaran yang menggunakan model ini adalah keterbatasan waktu sebagaimana yang disampaikan oleh Asita, dkk (2014) bahwa pembelajaran dengan model GI memakan waktu yang lama, sehingga guru perlu memperhatikan faktor pengelolaan waktu dalam 
menerapkannya. Kelebihan pembelajaran dengan model Group Investigation dengan pendekatan CTL yaitu (1) memungkinkan siswa dalam menggunakan kemampuan inkuiri yang membuat siswa lebih intensif dalam meneliti, mencari, dan menemukan pemecahan dari suatu masalah; (2) siswa yang berpartisipasi dalam Group Investigation cenderung berdiskusi dan menyumbangkan ide; (3) mendorong siswa untuk berpartisipasi aktif untuk memecahkan masalah, sehingga siswa dapat mengkonstruksi pengetahuan.

\section{KESIMPULAN}

\section{A. Simpulan}

Hasil analisis data diperoleh kualitas perangkat pembelajaran yang dikembangkan dinyatakan valid oleh pakar, keterbacaan BAS sangat tinggi dan mudah dipahami. RPP mencapai keterlaksanaan yang sangat baik, aktivitas siswa yang menonjol adalah merumuskan masalah, kendala yang terjadi dalam proses pembelajaran adalah siswa yang belum terbiasa melakukan penyelidikan sehingga membutuhkan waktu yang lama. Keterampilan berpikir kritis menunjukkan adanya peningkatan dengan kriteria $N$-Gain tinggi, sehingga perangkat pembelajaran dengan pendekatan CTL menggunakan model Group Investigation yang dikembangkan oleh penulis dapat digunakan untuk melatihkan keterampilan berpikir kritis siswa.

\section{B. Saran}

Pada penelitian menggunakan perangkat pembelajaran dengan pendekatan CTL menggunakan model kooperatif Group investigation untuk melatihkan keterampilan berpikir kritis siswa, peneliti menemukan beberapa kendala terutama dalam hal pengelolaan waktu. Oleh karena itu peneliti menyarankan perlu adanya pengarahan terlebih dahulu kepada siswa tentang model pembelajaran yang akan digunakan, selain itu siswa juga perlu dikondisikan terutama pada fase pemilihan topik yang akan dibahas dan fase penyelidikan.

\section{REFERENSI}

Alvino J. (1990) A Glossary of Thinking Skills Terms, Learning, 18 (6): 505

Borich, G. D. (1994). Observation Skills for Effective
Teaching. New York: Mcmillan Publishing Company

Dahar, R. W. (1989). Teori-Teori Belajar. Jakarta: Proyek Pengembangan Lembaga Pendidikan Tenaga Kependidikan

Duron, H., Limbach B., dan Wough. 2006. "Critical Thingking Framework to Any Dicipline." International Journal of Teaching and Learning in Higher Education. 17 (2): 160-166.

Ennis, R. H. (1996). Critical Thinking, New Jersey. Prentice. Hall. Inc.

Khaeruddin. 2013. Model Pembelajaran Fisika Berbasis Keterampilan Berpikir Kritis. Produk Disertasi Program Pascasarjana Program Studi Pendidikan Sains Universitas Negeri Surabaya

Komalasari, K. (2010). Pembelajaran Kontekstual Konsep dan Aplikasi. Bandung: Rafika Aditama

Mainali, B. P. (2011), Critical Thinking for Quality Education. Academic Voices A Multidisciplininary Journal Volume 1, No. 1.

Mulyasa. 2006. Kurikulum Tingkat Satuan Pendidikan. Bandung: PT. Remaja Rosdakarya.

Nieveen, N. (1999). Design Approaches and Tools in Education and Training. University of Twente, The Netherland: Springer-Science + Business, B.V

Prasetyowati, N. (2013). Model Pembelajaran Inkuiri pada Pokok Bahasan Larutan Penyangga untuk Meningkatkan Penguasaan Konsep dan Keterampilan Berpikir Kritis Siswa SMA. (Tesis tidak dipublikasikan ). Universitas Negeri Surabaya.

Ratumanan, T. G. dan Laurens, T. 2011. Penilaian Hasil Belajar pada Tingkat Satuan Pendidikan Edisi 2. Ambon: Unesa University Press

Siroj, R. A, (2004). Pemerolehan Pengetahuan Menurut Pandangan Konstruktivistik. (online). Tersedia: http://wwwdepdiknas.go.id/Jurnal/43/rusdy-asiroj.htm, diakses pada tanggal 15 Juli 2015.

Slavin, R. E. 2009. Psikologi Pendekatan Teori dan Pratik. Jakarta

Trilling, B. and Fadel, C. (2009). 21 st Century Skills Learning For Life in Our Times. San Fransisco: AWilley Imprint 